\title{
Moroccan Organic Doctrine Through the Lens of Dysfunctions of the Administrative Judicial System
}

\author{
Siyouri Hind \\ Public Law and Political Sciences, Al Kadi Ayyad University, Marrakech, Morocco
}

\author{
Email address: \\ Hindsiyouri18@gmail.com
}

To cite this article:

Siyouri Hind. Moroccan Organic Doctrine Through the Lens of Dysfunctions of the Administrative Judicial System. International Journal of Science, Technology and Society. Vol. 8, No. 3, 2020, pp. 63-69. doi: 10.11648/j.ijsts.20200803.16

Received: March 25, 2020; Accepted: April 13, 2020; Published: June 17, 2020

\begin{abstract}
If an organic doctrine does exist alongside a university doctrine thus forming a kind of "body reflex", they demonstrate, in this regard, the existence of two distinct modes of thought within the doctrine of administrative law, confirming by the same token the specific place that the members of the administrative jurisdictions hold within this one. Indeed, the doctrinal field was built in administrative law on the basis of a close link with the administrative judge. The education provided by members of administrative jurisdictions is a fundamental part of the doctrinal work of administrative law. They also participate in university research activity. Because the judge who creates the law is not a judge who opposes political power, but who is content to recall principles that apply to all, doctrine is rightly speaking of the " government spectrum of judges " to maintain that, in reality, judges do not govern, but that, over their power of interpretation, they may disregard the principle of the separation of powers. Nevertheless, the Moroccan administrative judicial system is the subject of several criticisms related mainly to its indifference towards the specificity and the technicality of Moroccan administrative law which requires special training and advanced experience of the judges in charge of cases belonging to administrative discipline.
\end{abstract}

Keywords: Organic Doctrine, Administrative Judge, Teaching, Normative Power, Judicial System

\section{Introduction}

The field of administrative law, as a relatively autonomous legal field, was set up around the assertion of the principle of the specificity of the law to be applied to the administration and correlatively of the differentiation of a body of professionals specialized in its implementation work - the administrative judge - and a body of specialists in its formatting and its systematization - the administrative doctrine - both interested in the assertion of the specificity and the relative autonomy of this right which knew no competitor and was the only "real" public law.

The essential question has traditionally been whether, by doctrine, reference should only be made to academics and researchers or whether it should be made up of members of administrative jurisdictions.

The doctrinal field was indeed built in administrative law on the basis of a close link (a real umbilical cord) with the administrative judge: it is by leaning on the jurisprudence that the administrativists have managed to conquer their autonomy compared to the privatists.
If university doctrine is common to administrative and private law, organic doctrine is specific to administrative law, it even reveals the specificity of its construction and the status of administrative jurisprudence. Jean Rivero wrote a beautiful sentence passed to posterity: "Doctrine was born on the lap of jurisprudence"[1], And it is this relationship between doctrine and jurisprudence that is specific to administrative law: it feeds on the jurisprudential source, whereas the civil law enjoys a written source, and the administrative jurisprudential source springs only thanks to the cooperation of the academic doctrine and the organic doctrine.

If, like the other legal fields, the field of administrative law tends to be structured between a pole "of interpretation of the doctrine, monopoly of the professors in charge of teaching" and a pole "of interpretation turned towards the practical evaluation of a particular case apanage of the magistrates who carry out acts of jurisprudence ", the specific methods of its constitution gave to its structuring original features, the magistrates themselves exercising an important doctrinal function. Thus "an organic doctrine coexists with the 
university doctrine by making it a severe competition" [2]. As a result, doctrine and jurisprudence form a theoretically inseparable but often disunited couple [3].

If an organic doctrine does exist alongside a university doctrine thus forming a kind of "body reflex", they demonstrate in this regard the existence of two distinct modes of thought within the doctrine of administrative law, confirming by the same token the specific place that the members of the administrative jurisdictions hold within this one. In addition to their normative power, some members of the Moroccan administrative courts have an ancillary teaching activity (2). However, this activity is confronted with several difficulties linked to the dysfunctions of the Moroccan administrative judicial system (3).

\section{The Administrative Judge Between Normative Power and Teaching Activity}

The teaching delivered by the administrative judge is certainly a fundamental part of the doctrinal work of administrative law (2.1). However, the latter exercises limited normative power (2.2).

\subsection{Teaching of Administrative Law by the Administrative Judge}

In Morocco as in France, many members of administrative jurisdictions hold an important place in the University. Dean Vedel said: "The Council of State is a home for teachers" [4]. In fact, many of them are recruited by the Faculties of Law and appointed Associate Professors in order to mainly teach administrative law or contentious administrative procedure; or to provide specific lectures or lessons in public law as temporary staff, which is more often the case for members of the courts of appeal and administrative courts.

Likewise, it is not uncommon to see members of the administrative court sitting on administrative law thesis juries. It could even be said that it is now difficult to conceive of defending a thesis in administrative law or administrative litigation without the presence of a member of the administrative jurisdiction on its jury. It is still common to find articles written by members of administrative jurisdictions in the Blends offered to academics [5]. The teaching delivered by members of administrative jurisdictions is a fundamental part of the doctrinal work of administrative law. In this regard, it should be noted that among the textbooks on administrative law are works written by magistrates [6]. Furthermore, these works were written on the basis of the courses that these magistrates gave [7]. In France, the treaty of Edouard Laferrière [8] was born from the course he gave at the faculty of Paris, the lectures of Léon Aucoc [9] from his course of administrative law at the Bridges and roads school, the course of administrative litigation of Raymond Odent [10] of his course at the Paris Institute of Political Studies, as well as the manual of administrative law by Guy Braibant and Bernard Stirn [11].
Members of administrative jurisdictions also participate in university research activity in administrative law. It is not uncommon to see them attend or participate in colloquiums during which they willingly explain the genesis or the evolution of certain jurisprudence [12].

Somewhat incidentally, it may also be noted that the independence necessary and consubstantial to the activity of teaching law enjoyed by academics [13], meets the independence of the members of the administrative jurisdiction and that of the administrative jurisdiction in full [14]. If the doctrine is necessarily independent [15], the members of the administrative jurisdiction certainly meet this condition. As guaranteed by the Moroccan constitution, it is also independently that the royal commissioners of law and law pronounce their conclusions. The independence of academics certainly has little to do with that of magistrates; however, this character is very common to them when viewed as members of the administrative law doctrine. It is with complete independence that the authors express themselves on administrative law, free from any consideration or influence from the bodies to which they belong. [16]

From the point of view of an organic criterion, which would consist of membership of the teaching staff, and if "to work as a doctrine consists in teaching", it seems difficult to be able to exclude the members of the administrative jurisdiction from the doctrine of administrative law. However, with regard to a material criterion, relating to the doctrinal production of the members of the administrative jurisdiction, the situation turns out to be more complex.

\subsection{The Normative Power of the Administrative Judge}

The question here is whether the power to create law can make the judge, whose doctrine regularly celebrates "res judicata", a judge who governs. Admittedly, the latter may effectively be called upon to govern in specific cases, but without necessarily exercising a normative power. [17]

\subsubsection{The Nature of the Jurisprudential Power of the Administrative Judge}

In administrative law, the praetorian necessity became all the more acute since, in the process of forming this essentially jurisprudential law, the judge was not satisfied with being the mouthpiece of the law, the doctrine drawing from it arguments to unanimously recognize its normative power [18], so that Jean Rivero saw it as a judge who governs [19]. However, if the administrative judge distinguished himself in the context of the requests addressed to him as the main source of administrative law, it was with the assistance of the various royal commissioners of right and law and of a doctrine more or less academic, to which comes the systematization of concepts such as recourse for excess of power, public service or general principles of law. In other words, the development of administrative law can be seen in the light of a beneficial dialogue between doctrine and case law [20]. In this two-part choir, the role of doctrine is historically decisive if it is understood in general. So decisive, 
moreover, that it is possible to admit that it admittedly first enshrined the rule of law and then accompanied, when it did not arouse it, the jurisprudential power of the judge thanks to authors like Romieu, Duguit, Hauriou, Jeze or Bouffandeau. [21]

However, it is less these considerations of political philosophy than more technical and practical concerns that will justify calling into question the pre-eminence of the judge in the material sources of administrative law. In view of the legislative and regulatory inflation making it possible and essential to draw up an administrative code [22], can administrative law be indefinitely jurisprudential? The judge is now content to find a solution to the case before him no longer necessarily having time to fix the main principles, absorbed as he is by the concern for a jurisdictional yield [23]. Some authors have therefore mentioned the decline of the power of the courts in favor of a jurisdictional power which, logically, restricts the role of the doctrine in the exercise of the normative power of the judge. However, by supporting the idea that the administrative judge is the interpreter and more and more exceptionally the co-author of legislative production, and by revealing the conceptual and empirical issues of comparative law [24], this production has gradually assumed the worrying features of treacherous. The current boom in dialogue between judges, on the one hand, and judges and other legal professionals, on the other, attests to this.

Heir to the jurisprudence of the colonial state through the mechanism of state succession, the Moroccan judge was criticized for his follow-up on French jurisprudence. In fact, implicit or explicit borrowing from it was often dictated beyond the logic of ease by the knock-on effect of the reception of French positive law established by bilateral cooperation agreements.

Defines, following Jean Rivero, the judge who governs as a judge who guides society, in particular by a free interpretation of the texts, and who take the power to define and maintain a national ideology and to preserve it by imposing respect for the ethical foundations of state unity is a nod to political science.

However, how can a judge "govern", in the sense of Jean Rivero, if the law of which he is the interpreter is an imported law, largely ineffective and, consequently, having only little influence over human behavior because it is disconnected from local realities? Also, for a long time, in Morocco, the judge of the excess of power observed some reluctance to receive appeals for excess of power directed against simple ministerial orders. It is that "the judge who receives "recklessly" such recourse risks being the accomplice of the applicant"[25]. The graph below illustrates the evolution of appeals for excessive power before Moroccan administrative courts since their creation.

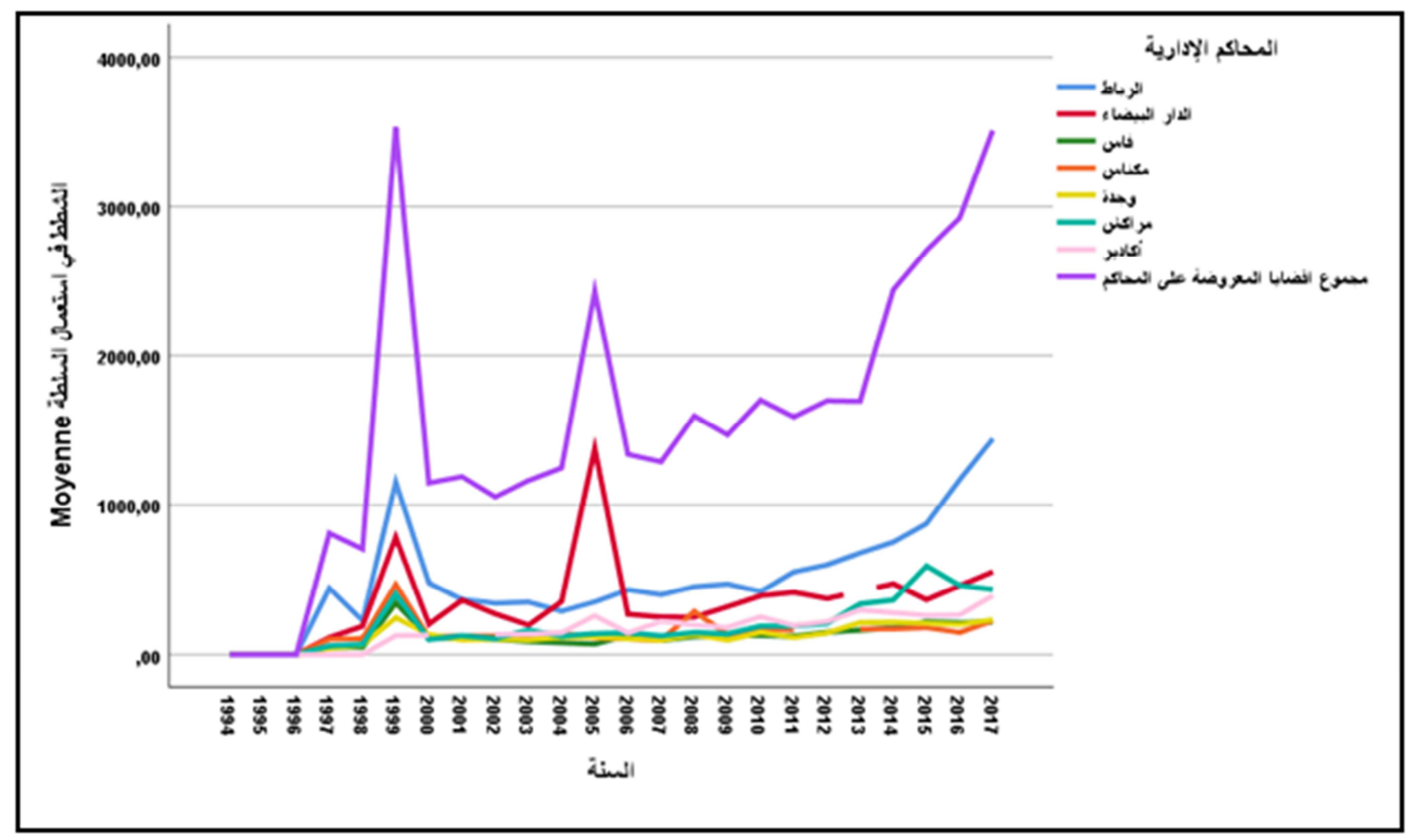

Figure 1. Evolution of recourse for excess of power before Moroccan administrative courts since their creation.

Beyond the rarity of such requests [26], this reservation by the judge has been enshrined in administrative procedural law which provides for graceful recourse, or administrative appeal, as a formal condition for the validity of the contentious appeal. The severity of the judge in controlling the formal requirements of certain contentious appeals appears to be a disguised support from the Administration and would translate in the worst case the "legality of fear". 


\subsubsection{Concern for the Respect of Public Freedoms and the Defense of Public Order}

The administrative judge, since he is the one who exercises a real normative power, was not always the judge whose present reinforced powers are known. The balance sought between respect for public freedoms and defense of public order has not always been easy. Faced with the imbalance in favor of an all-powerful administration, the appeal for excess of power seemed, to quote Gaston Jèze, "The most marvelous creation of jurists, the most effective, the most practical, the most economical weapon which exists in the world to defend liberties [28]" or, to use the Huron's praise, the" bulwark of the oppressed, terror of the oppressor who, when his arm is about to fall, stops when he hears the fearsome voice of the judge proclaiming: "you will not go further" [29].

However, for a long time, the administrative judge was content to annul the illegal decisions of the Administration, without enjoining him to behave in a certain way, and to punish it limply in financial terms.

Finally, to say that the judge is governing to dodge the controversial expression is nothing more than a truism, because, in both cases, it is incantatory, the expression being used in France for rhetorical purposes. Because the judge who creates the law is not a judge who opposes political power, but who is content to recall principles that apply to all, It is therefore right that the doctrine speaks of the "specter of the government of judges" to maintain that, in reality, judges do not govern, but that, over their power of interpretation, they may disregard the principle of the separation of powers. The fear of the government of judges has only fueled a French fantasy thus revealing the genealogy of a "dangerous misinterpretation". Not only does the judge who creates the law not govern, the better he does not exercise the normative power alone but jointly, to judge by the intensification of the dialogue of the judges, but also of the dialogue of the judges with the other professionals of the law as the lawyers. [30]

\section{Dysfunctions of the Moroccan Administrative Judicial System}

What is criticized on the Moroccan administrative judicial system is its indifference to the specificity and technicality of Moroccan administrative law which requires special training and advanced experience of judges responsible for cases in the administrative discipline. [31]

\subsection{Malfunctions Linked to Training}

It is indisputable that the administrative judge must have the means enabling him to maintain the level and the place that the legislator has devoted to him and therefore to ensure and guarantee moral respect for his decisions. This is only possible through a rational and adequate choice of the human element and the establishment of both initial (basic) specialized training and continuous training for the benefit of administrative judges. However, the majority of judges in administrative jurisdictions are recipients of training for ordinary judges or were previously ordinary judges who received training in private law that is different from administrative law. Next to these, we highlight the two special experiences carried out by officials in order to promote and support the body of judges in administrative courts.

The first experience was based on the choice of 12 judges as part of the 30th cohort in 2003 in order to benefit from internships in certain public administrations. The second concerns the integration of certain officials into judicial professions in accordance with article 5 of the Basic Law of Judges. They must undergo judicial training condensed in a limited time.

Regarding the first experience, according to the testimony of their presidents, the judges who received initial training in administrative law demonstrated high competence, despite their limited number [32]. However, such an experience has not been replicated and we are witnessing, rather, in the context of the reform of the judicial system, attempts to stop the consecration of judicial duality [33].

For its part, the second experience could have promoted the position of administrative justice by the integration of the administrative and technical executives exercising, however (in the absence of statistics and data on the subject) it did not retain the interest of the categories of administrative managers with good administrative and technical experience in the fields of finance, taxes and territorial administration as well as other sectors which can add value to administrative justice, or have not was well appreciated by the officials responsible for the selection of candidates who focused, in the process of integration in the judicial field, on civil servants belonging to the justice sector which prevented reaching the expected objectives of said experience.

\subsection{Malfunctions Related to Compliance with the Specificity and Technicality of Administrative Law}

At the time when we expected that the actors, within the framework of the reform of the judicial system, realize the specificity of administrative litigation by presenting proposals which can promote the position of administrative justice and overcome the practical dysfunctions of which it makes the purpose, in particular the strengthening of the training of administrative judges as well as the implementation of a code specific to the administrative procedure. The authors of the bill on the judicial organization saw that this organization must be based on the principle of the unicity of justice overseen at the top by the court of cassation, and that the various components of the judicial organization must work according to the principle of specialized justice. As a result, it seems that these authors have been against the completion of the administrative judicial system by the creation of the Council of State. And among the novelties contained in the judicial reform project, 
it is the possibility of providing the courts of first instance and the courts of appeal of certain departments specialized in administrative justice working under the aegis of the president of the court to which it belongs. These specialized departments are created following a decree fixing their number and the extent of their competence after consultation with the higher council of the judicial power. In addition, some practitioners show great concern with respect to the specificity and technicality of administrative law, in matters of judgments and decisions, by these departments. However, the above-mentioned bill is not final; its discussion by the legislature is likely to change this process, at least via the creation of new administrative tribunals instead of sections within ordinary courts.

\subsection{Some Avenues for Improving the Performance of the Administrative Judge}

Comparing the Moroccan experience with that of France, it is important to underline that in the framework of the second, half of the judges of the administrative courts are recruited from among the laureates of the national school of administration. The rest are selected from among state officials, those in the territorial administration, those in the health sector (grade A) with tenure of more than 10 years, and among judges of ordinary courts. There is also a specific system for recruiting advisers from administrators of the territorial administration, university professors, and certain civil servants with specified conditions as well as among the judges of the ordinary courts within the limit of a single post for six candidates for promotion.

In Morocco, it seems rigorous to reinforce, on the one hand, the training of judges of administrative courts, courts of appeal, and the administrative chamber of the court of cassation, not only on a theoretical level within the framework of the programs. of the Superior Council of Justice but also at the level of practice via the establishment of professional internships at the level of central and territorial administrations during the fundamental training of judges, and by the condensation of cooperation, in the field of training, between administration and administrative justice through the joint organization of symposia and training meetings, led by specialists on both sides, targeting the themes and areas that are problematic. As well as by setting up a mobility of administrative judges in the central administrations of the State and the territorial administrations in order to grasp the techniques of administrative law through the practical management of administrative files. Furthermore, it is important to also review the method of recruitment in the administrative courts of appeal and the administrative chamber of the Court of Cassation, limiting itself, for recruitment in these judicial institutions, to administrative judges who demonstrate competence professional and honesty, fully believing in the specificity of administrative law and its technique, and having judicial experience in administrative matters. These procedures are indeed likely to guide and inform the courts and administrative appeal courts and allow the administrative chamber of the Court of Cassation to fully play the role assigned to it in matters of enactment and the development of the law applied to administration [34].

The peculiarity of the position held by organic doctrine within the doctrine of administrative law is further revealed by the relationships it has with the other members of this doctrine, the academics. [35]

\section{Conclusion}

Insofar as jurisprudence has been the privileged, if not exclusive, mode of formation of administrative law, and still is largely today, one might think that organic doctrine has more titles than university doctrine to explain what jurisprudence is and to measure the scope of its judgments. The latter can rely on a double authority: the authority of the judge who decided the res judicata and the authority of the internal doctrine of the administrative tribunal which has access to the file and knows the debates which it provoked as well as the conclusions of the Royal Commissioner for right and Law. It is therefore an authorized opinion which these particular and authentic interpreters emit and which it is not welcome on the part of academic doctrine to question.

Because they write and teach, University doctrine and organic doctrine provide a function of dissemination of the law, in order to grant administrative law sufficient readability and accessibility to respond, not only to the canons of the state of right, that it is supposed to incarnate in the first place, but also to the imperatives of democracy. Indeed, these two doctrines play the same role in the "democratization of access to the law", particularly of a law known for its "incommunicability", even its "Byzantinism" and its "esotericism". These two doctrines would therefore be aware of sharing the same responsibility, perhaps the same mission, which is to participate in the construction of "legal knowledge", inherent in the full and entire realization of the state of right and its sustainability.

The doctrinal presence of the judge is obviously not without impact on the structure of the discourse (s) constituting the doctrine. This is necessarily dependent on an institution which, while producing the law, proceeds in its own way to the intellectual codification of knowledge specific to administrative law.

If it is admitted that administrative law is a case law, so that a legal thought can form on it, it is necessary that the decisions of case law are known to the possible authors. Knowing that "a true doctrine of administrative law could only flourish in the examination of case law", it is hardly surprising that it was the authors of this case law who were the first to develop the conceptual bases necessary for development of it. Nevertheless, it is indisputable that they must have the means enabling it to maintain the level and the place that the legislator has devoted to them and therefore to ensure and guarantee moral respect for its decisions. 


\section{References}

[1] J. RIVERO, "Jurisprudence and doctrine in the development of administrative law", ECDE 1955, p. 30.

[2] Y. POIRMEUR, E. FAYET, "administrative doctrine and the administrative judge; the crisis of a model for the production of law", C.U.R.A.P.P., p. 104.

[3] J. Philippe, "Doctrine and Jurisprudence: A Liaison of 25 Centuries", "4th Albert-Mayrand Conference, 2001", Thémis, 2004, p. 2.

[4] G. Vedel, “Jurisprudence and doctrine: two speeches”, RA, 1997, special issue, p. 10.

[5] see for example, administrative courts and State of law, work of the international colloquium organized by the law faculty, Marrakech, series: seminars and colloquia, $\mathrm{n}^{\circ}$ 5, 1996: Elmountassir Edaoudi, Advisor to the administrative chamber of the supreme court, p147. (In Arabic); the procedures followed before the administrative courts, work of the international conference organized by the law faculty, RabatSouissi June 15, 1996, REMALD, n 9, 1996.

[6] For example, Mohammed Bahi, Royal Commissioner of Law and right at the Administrative Court of Rabat, book entitled: Studies and comments on certain disputes in Moroccan administrative justice, REMALD, Coll. "Manuals and University Works", $\mathrm{n}^{\circ} 115,2017$. Mohamed Kasri, President of the administrative court of Rabat, The litigation relating to the tax base and the recovery of the tax before the administrative jurisdictions, REMALD, Coll. "Manuals and University Works", n 62, 2005.

[7] For example Mr. Bahi, counselor at the Casablanca Administrative Court and temporary teacher at the Faculty of Law, Casablanca.

[8] E. Laferriere, Treaty on administrative jurisdiction and contentious remedies, 2 volumes, Berger-Levrault, 1887-1888, reprint, LGDJ, 1989.

[9] L. Aucoc, Conferences on administration and administrative law, 3rd ed., 3 volumes, Dunod, 1885-1887.

[10] R. ODENT, Administrative litigation, 6th ed., Fasc. I to VI, Law courses, Paris, 1977-1981, re-edition, 2 volumes, Dalloz, 2007.

[11] G. Braibant, B. Stirn, French administrative law, 7th ed., Political Science Press - Dalloz, 2005.

[12] Administrative courts and State of law, work of the international colloquium organized by the law faculty, Marrakech, series: seminars and colloquia, $\mathrm{n}^{\circ}$ 5, 1996: Elmountassir Edaoudi, Advisor to the administrative chamber of the Supreme Court, p147. In arabic; the procedures followed before the administrative courts, work of the international conference organized by the law faculty, RabatSouissi June 15, 1996, REMALD, n 9, 1996.

[13] See Oleg Curbatov. Academic freedoms as vectors of higher education and Peace. IAUPL / CEPN. Dynamic and critical views of the governance of universities, 2017, G. VEDEL, "University freedoms", Review of higher education, 1960, p. 134; C. MONIOLLE, "Independence and freedom of expression of teacher-researchers", AJDA, 2001, p. 226.

[14] It is mainly a question of the principles of independence or even of the judicial authority (art. 82) and the irremovability of the magistrates of the seat (art. 85) of the constitution.

[15] O. BEAUD, "Doctrine", in Dictionary of legal culture, PUF, 2003, p. 386; D. TRUCHET, "Some remarks on the doctrine in administrative law", Mélanges Amselek, Bruylant, 2005, p. 771 .

[16] M. Deguergue, University Doctrine and Organic Doctrine, in Doctrine in administrative law, French Associations of Administrative Law (AFDA), $\mathrm{n}^{\circ}$ 3, Litec, 2010.

[17] Toko, P. W. Is the judge who creates the law a judge who governs?, Les Cahiers de droit, 54 (1), 2013.145-174. p. 148.

[18] This is particularly the case since the article by Marcel Waline, "The normative power of jurisprudence", in The technique and principles of public law. Studies in honor of Georges Scelle, Paris, L.G.D.J., 1950, p. 613.

[19] Jean RIVERO, "The French administrative judge: a judge who governs", in André de LAUBADERE and others, Pages of doctrine, t. 2, Paris, L.G.D.J., 1980, p. 303.

[20] J. RIVERO, "Apology for the" makers of systems "'", in André de LAUBADERE and others, Pages of doctrine, t. 1, Paris, L.G.D.J., 1980, p. 3; J. RIVERO, "Jurisprudence and doctrine in the development of administrative law", in A. de LAUBADERE et al., Cited above, note 46, p. 63.

[21] Toko, P. W., op.cit., p. 151.

[22] G. Vedel, "Can administrative law be indefinitely jurisprudential?", In France, Council of State, Studies and documents, no 31, Paris, National printing house, 1980, p. 31.

[23] D. Linotte, "Decline of Jurisdictional Power and Rise of Jurisdictional Power in Administrative Law", A.J.D.A. 1980. doctr. 631.

[24] The collective work edited by F. Melleray (ed.), The comparative law argument in French administrative law, Brussels, Bruylant, 2007, illustrates the interest of the question for academic legal doctrine. Read also the article by MarieClaire Ponthoreau, "Comparative law in question (s) between pragmatism and epistemological tool", R.I.D.C. 2005.1.7.

[25] D-M. Bléou, "The administrative chamber of the Supreme Court of Côte d'Ivoire", in Gérard Conac and Jean du Bois de Gaudusson (dir.), The Supreme Courts in Africa, t. 3 "Administrative jurisprudence", Paris, Economica, 1989, p. 112, at page 124. Judge Zoro Epiphane Ballo in Côte d'Ivoire illustrates this politicization of justice by justifying by law the establishment of the nationality certificate of Alassane Dramane Ouattara, one of the potential contenders for the supreme office, this judge has known serious difficulties.

[26] Especially since, according to a still widespread idea which says a lot about the insufficient institutionalization of political power, to bring an action against his hierarchical superior, it is to declare hostilities to the State.

[27] Toko, P. W. (2013). op.cit., p158.

[28] M-A. Flamme, Administrative law, Brussels, Bruylant, 1989, p. 613.

[29] J. Rivero, "The Huron at the Royal Palace or naive reflections on the appeal for excess of power", in A. de Laubadère et al., Cited above, note 11, p. 329. 
[30] Toko, P. W., op.cit., p. 160.

[31] M. Rousset, "Plea for the administrative chamber of the supreme court", REMALD, n 99-100, July-October 2011, p. 18 .

[32] In this context, the testimony of the late Mustapha Etterab, president of the administrative court of appeal in Rabat, on the occasion of the fourth anniversary of the entry into operation of the administrative courts of appeal in 2011.

[33] M. Bahi, Studies and comments on certain litigations of Moroccan administrative justice, REMALD, Collection "Manuals and university works", n 115, 2017. (In Arabic).
[34] M. El Yaagoubi, "the regulatory role of the administrative chamber of the supreme court", Legal and Political Review: Independence and Cooperation, $\mathrm{n}^{\circ} 1, \mathrm{p} .81$. Quoted by $\mathrm{M}$. Rousset, op.cit., P. 16. See also M-A. Benabdallah, "Reflections on the law establishing administrative courts of appeal", REMALD, n 68, 2006, p. 9.

[35] A. Ciaudo, "Back on some paradoxes: the administrative judge and the doctrine of administrative law", Blog Droit administrative, June 8, 2007. 